\title{
INDIVIDUAL MOVEMENTS IN SERVICE FACILITIES BY UTILIZING ONLINE TRANSPORTATION SERVICES IN GEOSPATIAL PRESPECTIVES
}

\author{
Sakinah Fathrunnadi Shalihati ${ }^{1}$, Anang Widhi Nirwansyah ${ }^{2}$ \\ Universitas Muhammadiyah Purwokerto \\ Email : sakinahfs@ump.ac.id
}

Keyword :

Individual

Movements, Service

Facilities, Online

Transportation

Services, Geospatial.

DOI :

10.30595/jssh.v3i2.5435

\begin{abstract}
The application of online transportation services increasingly free any individual to move to have outside activities in more than one place in a certain period of time. Individuals are free to choose what mode of transportation to use and when to use it with transparent costs or even with life insurance provision. This study aimed to find out the individuals' movement in service facilities by utilizing online transportation services in Purwokerto Urban Area in Geospatial Perspective. This study used survey methods and proportional sampling with 40 people as the samples. The results showed that individual movements in various service facilities by utilizing online transportation services were so varied. From a total of 809 movements, 156 movements were done by male users and 653 movements by female users. It is distributed to the destination place from the highest, namely education, economic, community, health, and public facilities.
\end{abstract}

\section{INTRODUCTION}

Transportation means the activity of moving goods and people from a place of origin to a destination (Origin-Destination Travel). People who use transportation services usually intend to work, to trade, to attend meetings / discussions, or to do other activities (Nasution, 2004; Adisasmita, 2011). Transport activity is an element of geography because it can be studied in terms of space variables and it can also determine the boundaries and characteristics of an area (Golledge, 1964).

The development of increasingly advanced digital technology during this industrial revolution 4.0 contributed to the progress of transportation. One of the advancements that has been made is the availability of online transportation services. This online transportation service business does not require a corporation but only technology information applications, so application owners do not need to go into the transportation business but only facilitate or make it easier to meet the driver with service providers transportation (Pribadiono, 2016).

This transportation progress makes it easier for more flexible movements to occur. Movements can be in the form of movement of people, vehicles and goods which will lead to various kinds of interactions, such as interactions between cities as markets and industrial areas (Tamin \& Frazila, 1997). Interactions that occur due to the movement of human flow are certainly not simple, considering that every individual now has easier access to information technology in the form of a smart phone connected to the internet network, therefore, it is very easy to download the online transportation service.

The application of online transportation services is increasing that never limits every individual to carry out activities in 
more than one place in a certain period of time, because individuals are free to choose what mode of transportation to use, when to use it with transparent costs or even with life insurance provision. Individual movements can occur in the same service facilities or different service facilities. Service facilities consist of education, health, economic, community and public service facilities (Muta'ali, 2015).

Purwokerto Urban is one of the urban areas including North Purwokerto, East Purwokerto, South Purwokerto and West Purwokerto Districts which experienced rapid growth in all fields, such as education, health, trade, shopping, banking and services (Wibowo, 2014). The rapid growth of Purwokerto Urban is certainly influenced by the ease of existing transportation activities, so that the interaction formed becomes faster. It is important to examine the extent of the use of online transportation services that have developed in Purwokerto, so that this study will provide information on individual movements in service facilities by utilizing online transportation services in the
Geospatial Urban Area in Geospatial and the results obtained can be used to develop Purwokerto Urban become one of the Smart City in Indonesia.

\section{METHOD}

This study uses a survey method. Survey method is research conducted by a questionnaire as a research technique carried out in large and small populations. However, the sample data are taken from the population, so that events, distribution and relationships between the variables of sociological and psychological were found (Sugiyono, 2013).

The sample of this study is proportional sampling with 40 residents in the Purwokerto Urban Area using Online Transportation Services. The questionnaire data were collected from 12 December 2018 to 2 January 2019.

Questionnaires as a technique of collecting data were done by giving respondents a list of questions as a means to gather information about the individual's behavior in using online transportation services.

Table 1.Table of Research Questionnaire

\begin{tabular}{lll}
\hline Indicator & Item & Total item \\
\hline The identity of individual respondent & 1 & \\
a. Name & 2 & \\
b. Age & 3 & 4 \\
c. Sex & 4 & \\
d. Address & &
\end{tabular}

Characteristics of Online Transportation Services
a. Type of Online Transportation Services
b. Duration of use
5
6

History of Spatial Movements

a. Types of Service Facilities

b. Movement Frequency to Service Facilities

Total

7

8
The data processing of this research uses the help of Microsoft Excel software for the results of the questionnaire that has been filled in by the samples / respondents. It was then processed through three stages, namely reducing data, presenting data and 
drawing conclusions (Sugiyono, 2013). Data reduction is done when tabulating the results of the questionnaires. The tabulation results are displayed in the form of diagrams / graphs, and then analyzed to draw conclusions.

The individual movements in service facilities using online transportation services in a geospatial perspective are displayed in the form of maps. Map Making requires interpretation of satellite images from remote sensing data of Google Earth imagery, carried out to identify land use and distribution of individual movements at the location of service facilities in Purwokerto Urban Area. The interpretation of land use uses visual interpretation techniques in ArcGIS 10.4 software applications.

The results of questionnaire processing and mapping of individual movements in service facilities by utilizing online transportation services were then analyzed in a qualitative descriptive manner.

Table 2. Respondents Characteristics

\begin{tabular}{lll}
\hline Respondents & Characteristics & $\%$ \\
\hline Gender & Male & 46,7 \\
& Female & 53,3 \\
\hline Age & $<20$ years old & 16,2 \\
& 20-29 years old & 72,4 \\
& 30-39 years old & 7,6 \\
& 40-49 years old & 3,8 \\
\hline Marital & Single & 77,1 \\
Status & Married & 22,9 \\
\hline Occupation & Housewife & 4,8 \\
& Private Officer & 21,9 \\
& Students & 51,4 \\
& Engineer & 1,0 \\
& Civil Servants & 12,4 \\
& Entrepreneur & 8,6 \\
\hline Income & $<2$ millions IDR & 67,6 \\
& 2-5 millions IDR & 16,2 \\
& $>5$ millions IDR & 16,2 \\
\hline
\end{tabular}

Classical assumption examination is normality with normal graphic P-P Plot and Kolmogorov-Smirnov test. Normal graphic
P-P Plot shows normal pattern with data range point following diagonal line, this result inline with Kolmogorov-Smirnov value which is 0,910 , asymp. sig. (2-tailed) as $0,380>0,05$ stated normal residual data. Second classical assumption examination is multicollinearity with tolerance value for cultural $(0,588)$, social $(0,511)$, and personal $(0,725)>0,1$ and value of Variance Inflation Factor for cultural $(1,700)$, social $(1,958)$ and personal $(1,379),<10$ which means there is no multicollinearity in regression model. Third examination is heteroscedasticity with scatterplot graphic and Glejser test. The result of scatterplot graphic shows data are spread in up above 0 point $y$ axis, It is inline with cultural factor probability $(0,890)$, social $(0,724)$, and personal $(0,305)>$ 0,05 there is no heteroscedasticity in regression model.

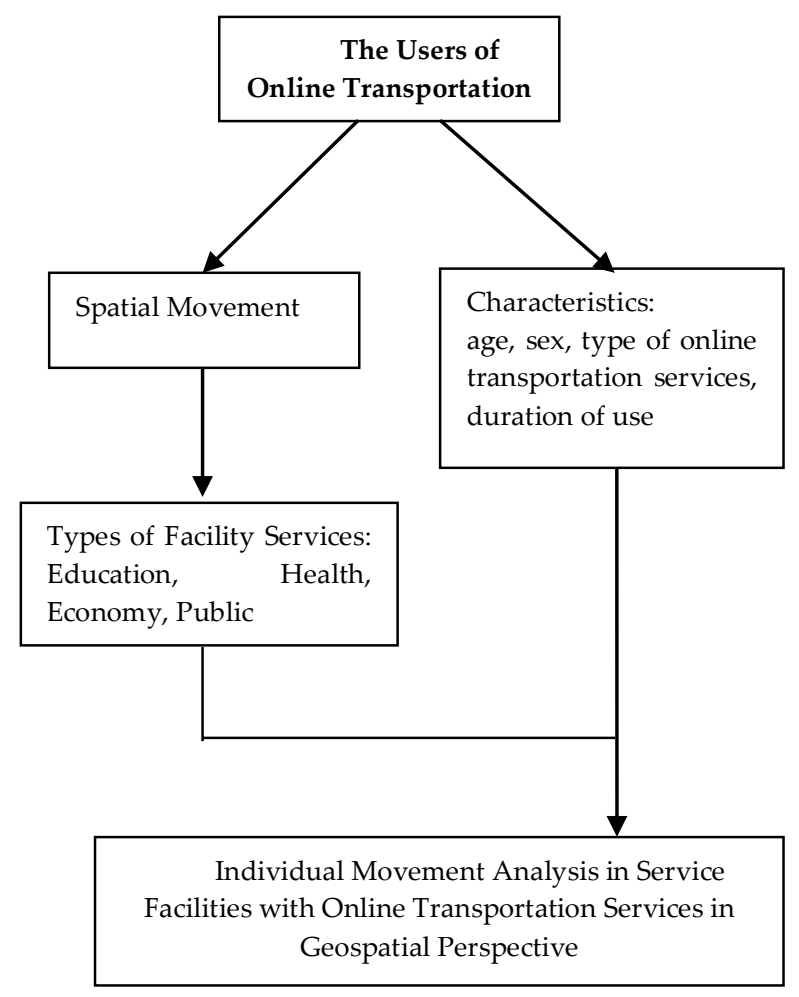

Figure 1. Diagram Flow of research implementation 


\section{RESULT AND DISCUSSION}

\subsection{Respondents using Online}

\section{Transportation Services}

The reduced and tabulated questionnaires show the classification/ distributions of 40 individuals using online transportation services:

1. By sex: The dominance of users of online transportation services is 24 women $(60 \%)$ and 16 men (40\%).

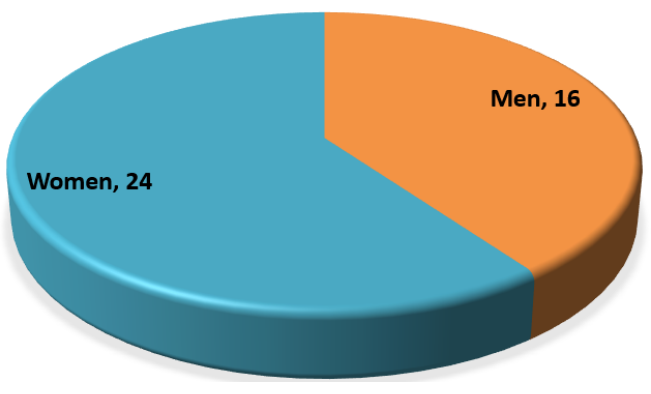

Figure 2. individuals using online transportation services based on sex

2. By age: The dominance of the age of users of online transportation services is above 15 years or at productive age with 15 men and 22 women, and under 15 years with only 1 male and 2 female users.

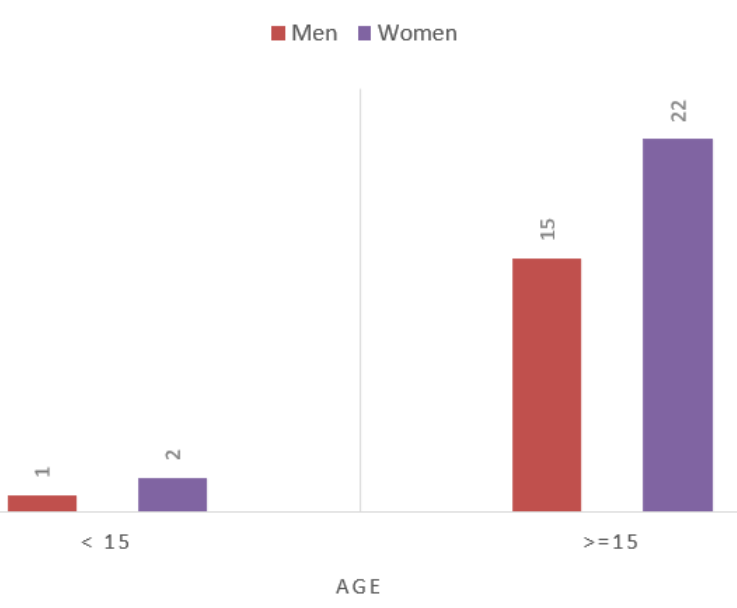

Figure 3. the age of users of online transportation

3. By the type of online transportation services: Gojek is the most popular online transportation services, there are 7 male users and 14 female users. Meanwhile, Grab online transportation services are used by 3 men and 4 women. Gojek and Grab online transportation services are used alternately by 6 men and 6 women.

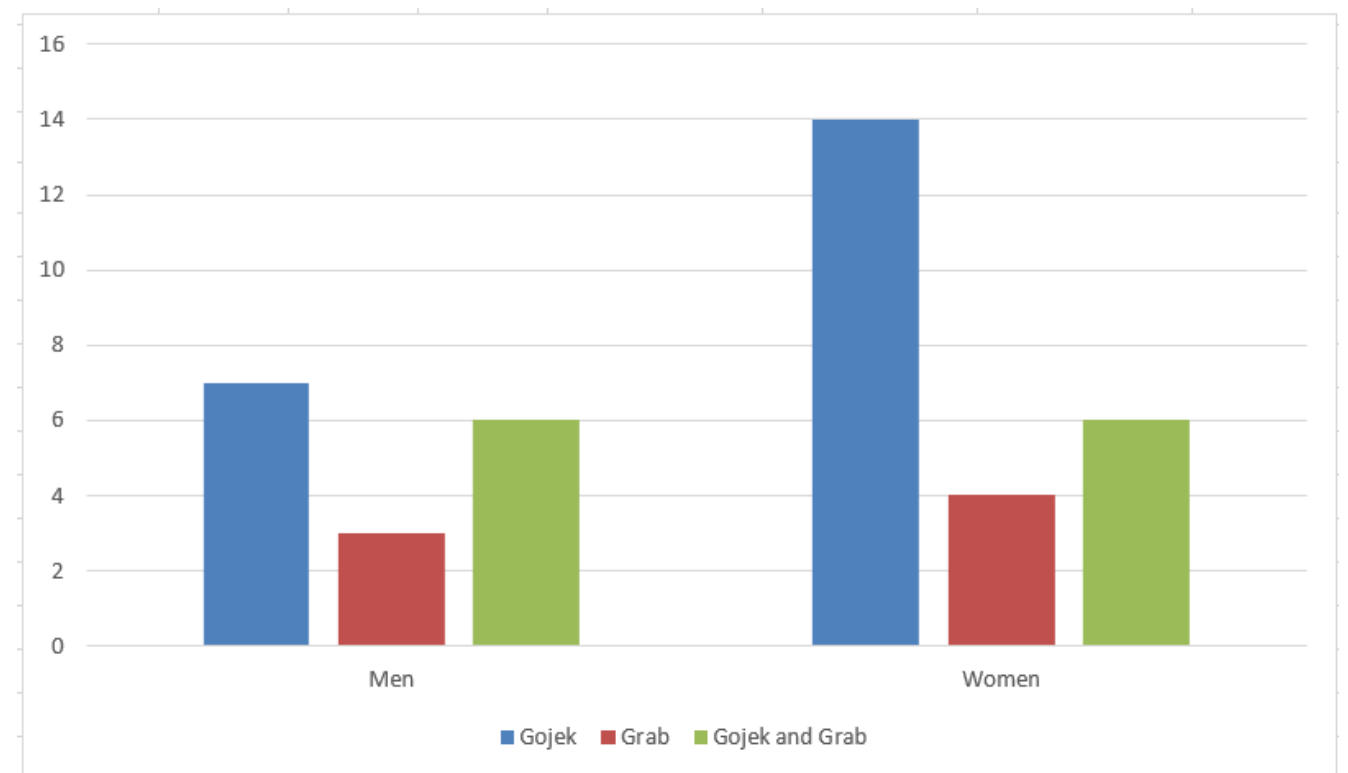

Figure 4. Diagram Flow of research implementation 
4. By the use duration of online transportation services: The use duration of online transportation services are grouped into 2 , namely $\leq 12$ months / 1 year and $>12$ months / 1 year. There are users of 16 men and 21 women in the duration of users $\leq 12$ months and there are only 3 women in the duration of users $>12$ months

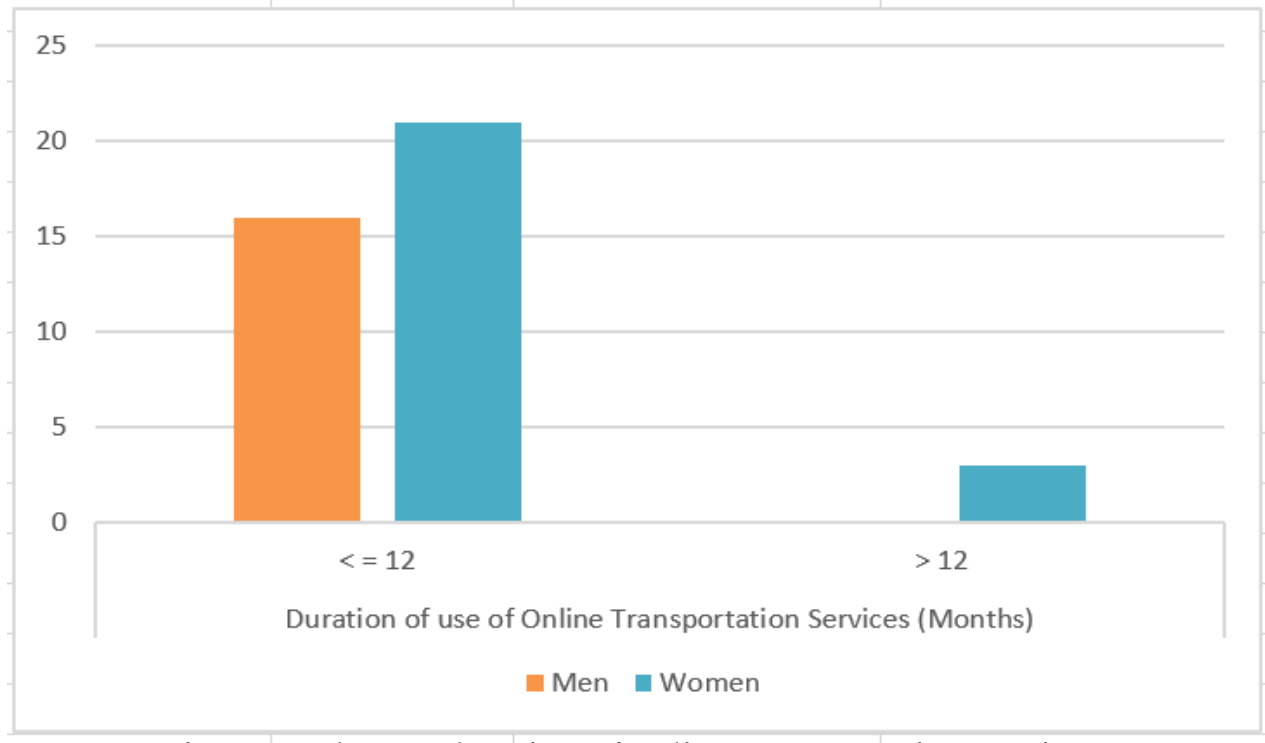

Figure 5. The use duration of online transportation services

3.2. The Distribution of Individual Movement Spatial in Service Facilities by Utilizing Online Transportation Services

Individual movements in various service facilities by utilizing online transportation services are so varied, with a total number of 809 movements consisting of 156 male users and 653 female users, each of which can be described as follows:

1. Educational Facilities: Spread over 8 points, 25 movements by male user, and 437 movements female user, with the most number of movements to
Universitas Jenderal Sudirman (UNSOED) with 214 movements, then SMP N 3 Purwokerto with 88 movements, SMA N 4 Purwokerto with 50 movements, Universitas Muhammadiyah Purwokerto with 49 movements, SMP N 1 Purwokerto with 46 movements, SMA N 5 Purwokerto with 10 movements, SMP N 9 Purwokerto SMP N with 3 movements and SD N 4 Teluk with 2 movements, these movements are shown in Figure 6. 


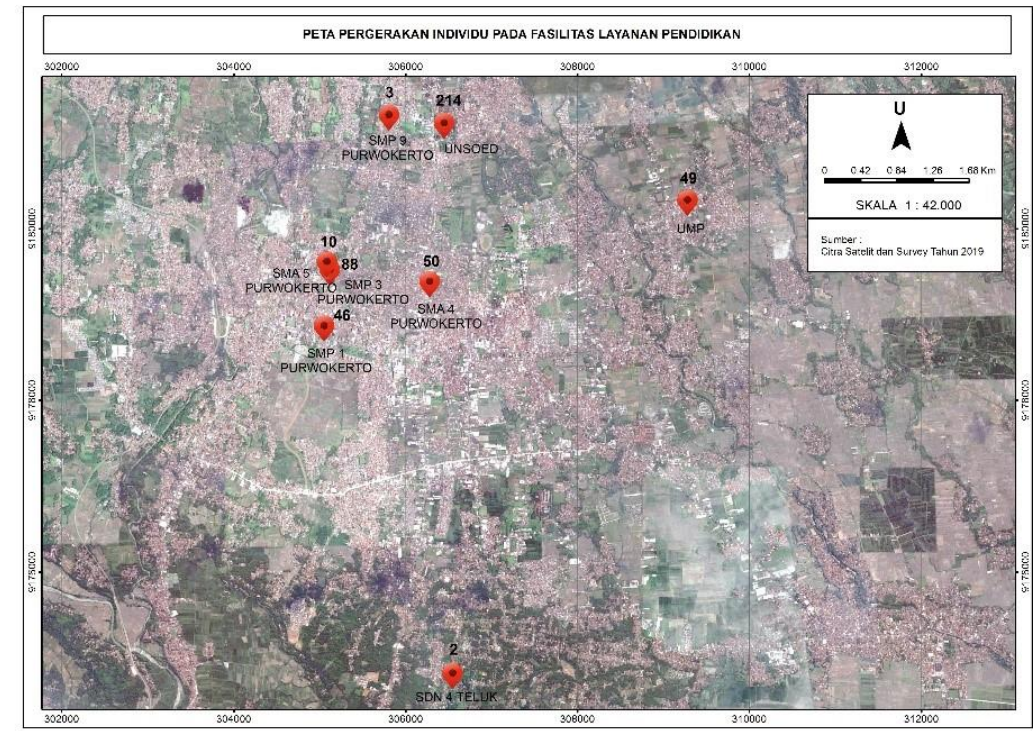

Figure 6. Map of Individual Movement of Educational Service Facilities

2. Economic Facilities: The highest number is the destination to Rita Supermall with 77 movements, Moro Mall with 38 movements, Tanjuri Gandasari Salon with 11 movements, Paparonz Pizza with 8 movements, Manis Market with 7 movements, and other locations with few movements but not significant in number. 30 movements by male user and 137 movements by female user.

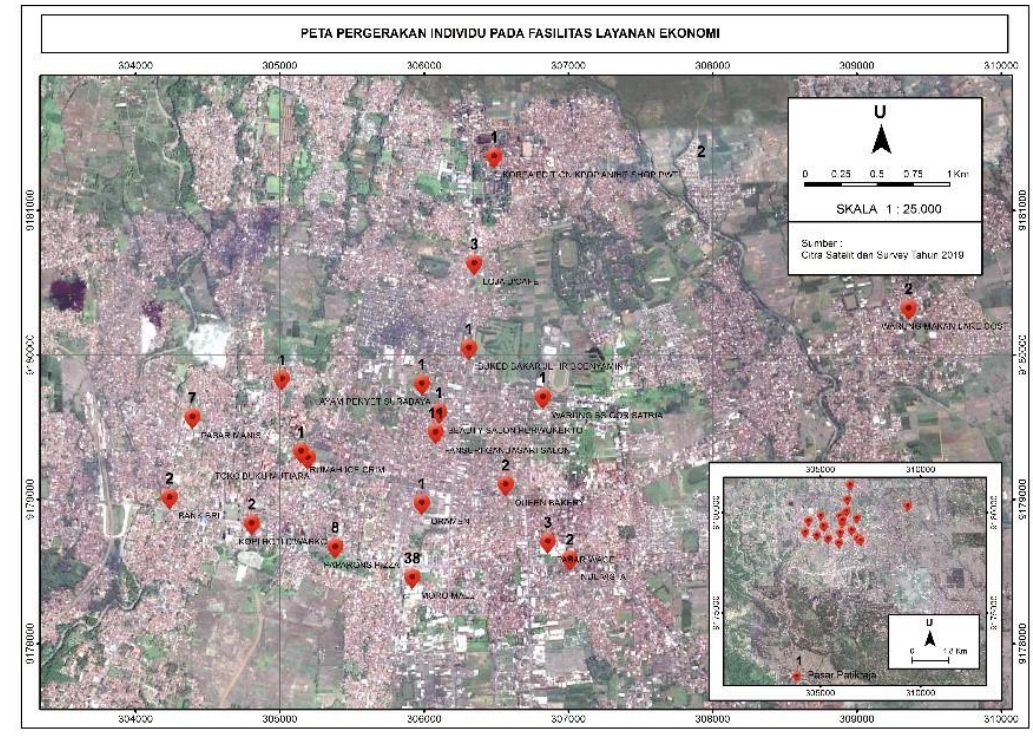

Figure 7. Map of Individual Movement on Economic Service Facilities

3. Health Facilities: 16 movements by male user and 3 movements by female user. It shows a wider range, there are users going to health facilities in the vicinity of Purwokerto and outside the district. Figure 8 shows the most movement is to Margono Soekarjo Hospital with 14 movements, to PMI (Indonesian Red Cross Society) clinic of Purbalingga with 3 movements, and to the Banyumas Health Service and to Public Health Center (Puskesmas) 1 East 
Purwokerto with a single movement each.

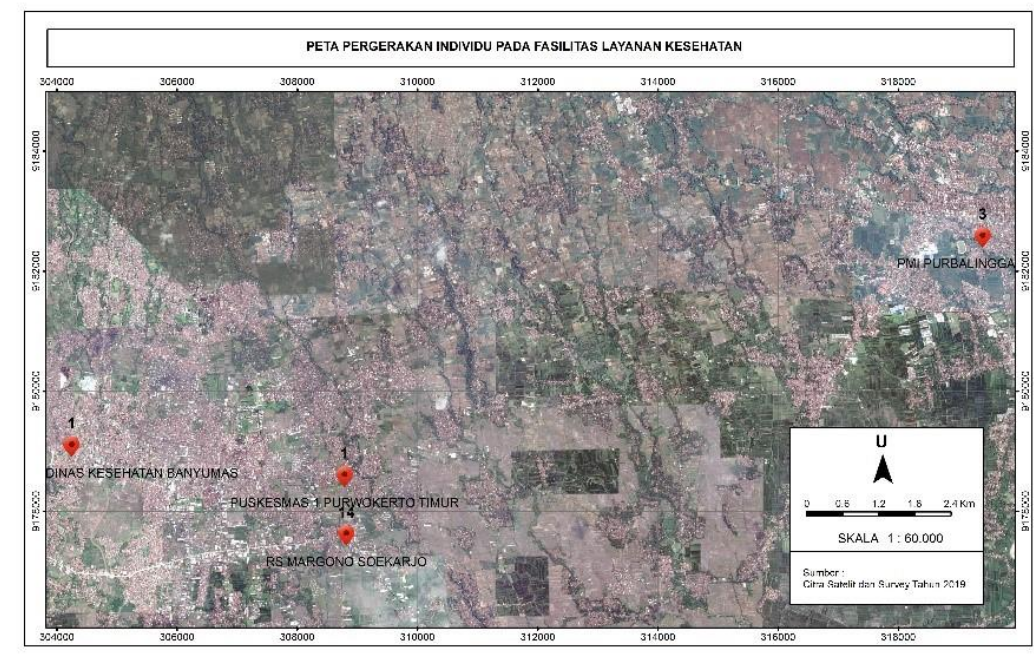

Figure 8. Map of Individual Movement on Health Service Facilities

4. Public Facilities: 5 movements by female user. Figure 9 shows the most movement to Banyumas Kwarcab as many as 3 movements, and to DPPKB3A and to Population and Civil Registration Agency, of Banyumas with a single movement each.

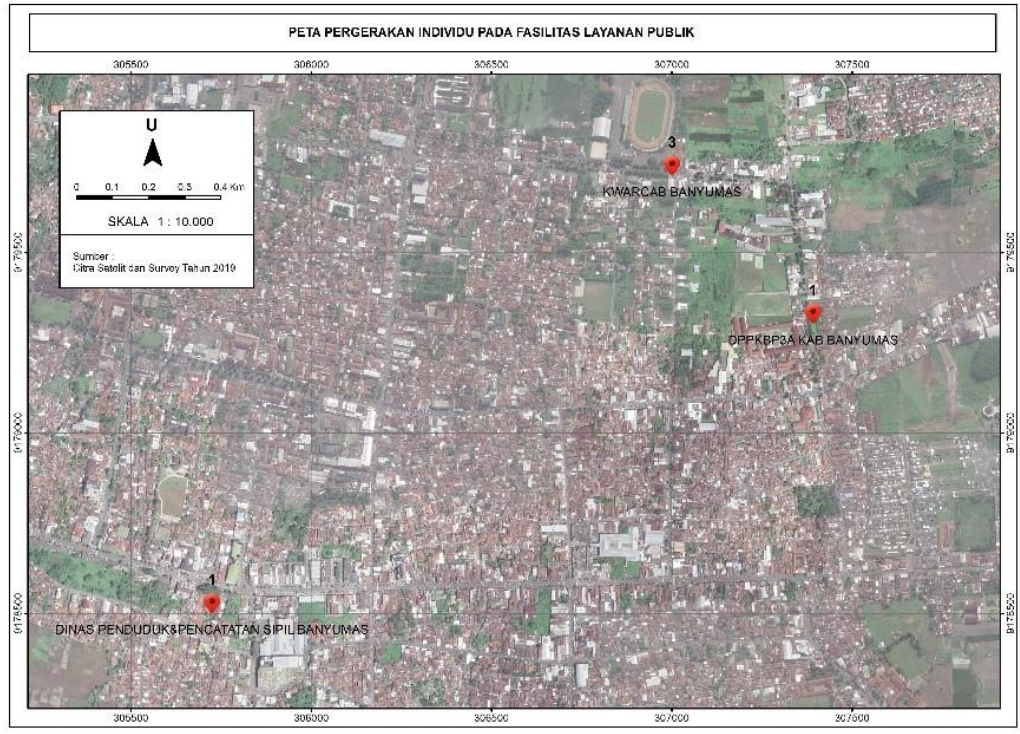

Figure 9. Map of Individual Movement in Public Service Facilities

5. General Facilities: 85 movements by male user and 71 movements by female user. Dominant movement to Purwokerto railway station is found with 79 movements, to Alun-alun (public square) of Purwokerto with 21 movements, Orion Futsal with 12 movement, GOR (Sport Hall) Satria with 10 movements. The rest of the other movements are shown in Figure 10. 


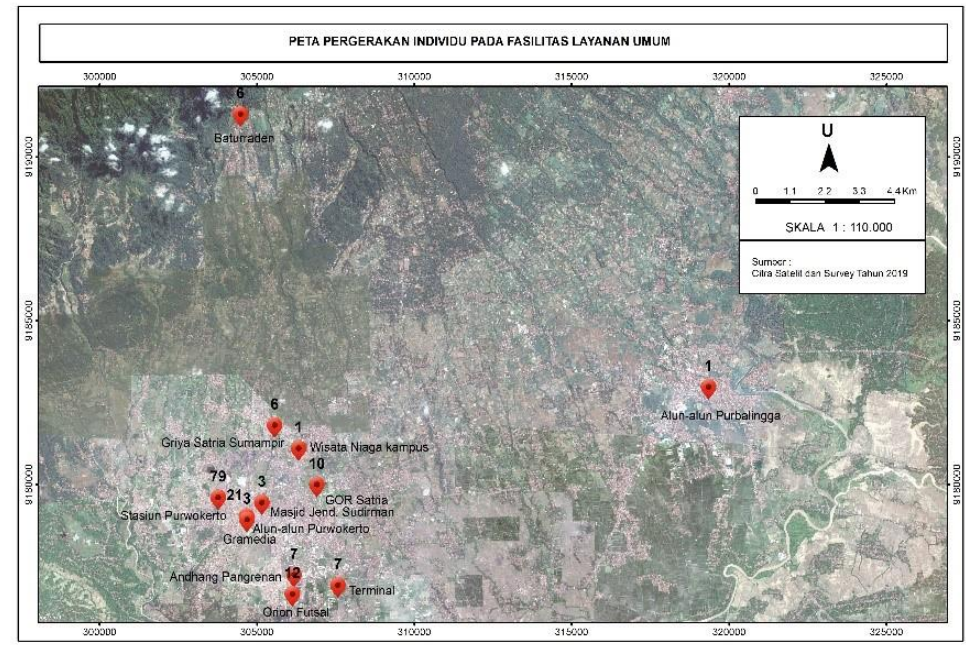

Figure 10. Map of Individual Movement in General Service Facilities

From the distribution, it can be briefly explained that male users make the most movements to public facilities, while

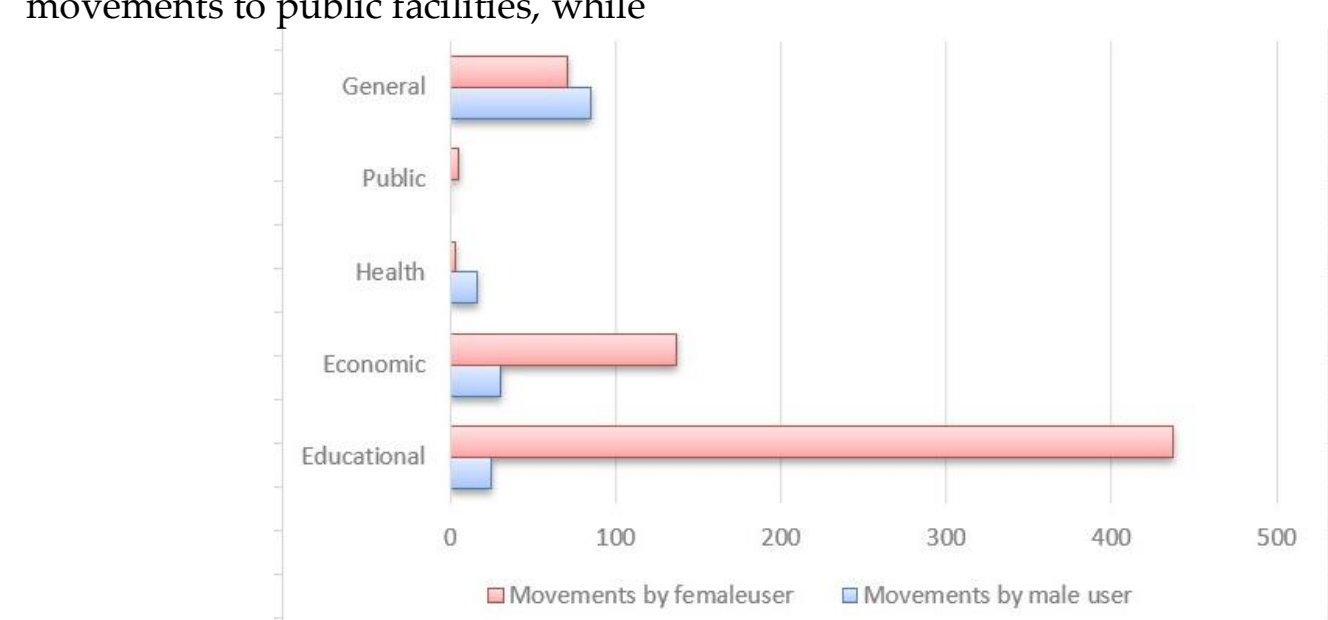

female users make the most movement to educational facilities.

Figure 11. Individual Movement Charts at Service Facilities by Utilizing Online Transportation Services

\section{CONCLUSION}

There were 809 movements consisting of 156 male users and 653 female users. There were 462 movements to education facilities, 167 to economic facilities, 19 to health facilities, 5 to community facilities, and 156 public facilities.

The results of this study can be used for the development of government transportation planning in paying attention to the needs of the movements dominating the community, so that the availability of transportation equipment is more effective in its use.

There needs to be more in-depth research related to online transportation services, such as their impact on other manual / regular transportation services, the effectiveness of online transportation services used, and the effect of socioeconomic community for users of online transportation service (whether it is useful or not). 


\section{REFERENCES}

Adisasmita, S. A. (2011). Transportasi dan Pengembangan Wilayah (1st ed.). Yogyakarta: Graha Ilmu.

Golledge, R. G. (1964). ECONOMIC GEOGRAPHY. By John W. Alexander. https://doi.org/10.1111/j.17457939.1964.tb00140.x

Muta'ali, L. (2015). Teknik Analisis Regional untuk Perencanaan Wilayah, Tata Ruang dan Lingkungan. Yogyakarta: Badan Penerbit Fakultas Geografi Universitas Gadjah Mada.

Nasution, M. N. (2004). Manajemen Transportasi (2nd ed.; M. S. Qadhafi, ed.). Jakarta: Ghalia Indonesia.
Pribadiono, A. (2016). Transportasi Online Vs Transportasi Tradisional NonOnline Persaingan Tidak Sehat Aspek Pemanfaatan Aplikasi Oleh Penyelenggara On Line. Lex Jurnalica, 13(2), 126-138.

Sugiyono. (2013). Metode Penelitian Pendidikan. Bandung: ALFABETA,cv.

Tamin, O. Z., \& Frazila, R. B. (1997). Penerapan Konsep Interaksi Tata Guna Lahan-Sistem Transportasi Dalam Perencanaan Sistem Jaringan Transportasi. Perencanaan Wilayah Dan Kota, 8(3), 34-52.

Wibowo, A. (2014). Studi Tentang Struktur Kota dan Sistem Transportasi di Perkotaan Purwokerto Tahun 2013. Geoedukasi, III(1987), 68-76. 